\title{
Ekon av Hårda tider
}

Reception och bruk av K.A. Tavaststjernas nödårsroman

Det Är minerad MARK som Karl August Tavaststjerna (I86o-I898) ger sig ut på när hans andra roman Hårda tider utkommer i december I89r. ${ }^{1}$ Undertiteln, Berättelse från Finlands sista nödår, syftar på ett finländskt trauma: den katastrof av undernäring och epidemier som mindre än 25 år tidigare hade decimerat landets befolkning med upp till en tiondel. Många av de tidiga läsarna hade själva minnen från hungeråren.

Ämnet är stort. Också förväntningarna är det. I synnerhet anhängare av den litterära strömning som Georg Brandes I883 kallat"det moderna genombrottet" ${ }^{2}$ har ögonen på den 3 I-åriga Tavaststjerna, en sedan debuten 1883 uppskattad lyriker. Med prosadebuten Barndomsvänner ${ }^{3}$ I886 har Tavaststjerna definitivt skrivit in sig i den nordiska avdelningen av kolleger till naturalistiska pionjärer som Flaubert och Zola. Samtidigt är han, just därför, kontroversiell i ett kulturklimat dominerat av patriotisk idealism, och där, med Arne Toftegaard Pedersens ord, "Runebergs vapendragare ännu dominerade kritiken". ${ }^{4}$

En tidigare version av texten lades fram som proseminarieuppsats i ämnet Svensk litteratur, Helsingfors universitet, I5/ıo I980. Publicerad 2020 på http://www.saunalahti.fi/ trygvsod/slammer/I980/Ekon_av_Harda tider_I980.html (hämtad 2I/5 202I).

I. Karl A. Tavaststjerna, Hårda tider. Berättelse från Finlands sista nödår, Helsingfors: Söderström I89I.

2. Georg Brandes, Det moderne Gjennembruds Mand. En rakke portrater, Kjøbenhavn: Gyldendalske Boghandel I883.

3. Karl A. Tavaststjerna, Barndomsvänner. Ett nutidsöde, Borgå: Werner Söderström I886.

4. Arne Toftegaard Pedersen, "Skrif som Runeberg, gossar! Nationalskalden och åttiotalisterna", Pia Forssell \& John Strömberg (red.), Historiska och litteraturhistoriska studier 79, Helsingfors: Svenska litteratursällskapet i Finland 2004, s. 266. För en 
Det krassa temat för Barndomsvänner är en ung, begåvad sångares uppgång och fall - det antyds att syfilis förstör hans stämband. Romanen har undertiteln "Ett nutidsöde", och när Tavaststjerna nu, fem år senare, väljer hungeråren på I86o-talet som tema, finns i det naturalistiska lägret en förväntan på en lika oförställd blick på närhistorien.

Den förväntan infrias - Hårda tider håller ett ofta ännu skarpare tonfall än Barndomsvänner. Samhällskritiken är tydligare uttalad på alla romanens tre tangerande plan: folkets, herrskapets och "överhetens".

I det folkliga intrigsegmentet har österbottningen Kalle Pihl övergett hustru och barn och dragit till Tavastland där han lyckas ingå ett förmånligt tvegifte. Han baserar det på ett falskt papper: Lehtimaa, också österbottning, men ogift, har sålt honom sitt prästbetyg. Förvirrad av hunger, avund och en föreställning om att vara "utvald till ett Guds straffande värktyg" mördar Lehtimaa Pihl och hans nya hustru. Bägge de folkliga huvudpersonerna blir alltså under handlingens gång brottslingar: den ena bedragare, den andra mördare.

Också herrgårdsfolket och landets regering granskas bitvis med kritisk blick - uttalad eller underförstådd. Till exempel har godsägaren Thoreld övertalat Kalle Pihl att gifta sig med mejerskan Anna Mellilä, Thorelds före detta älskarinna som han vill göra sig av med för att kunna sikta på ett mera ståndsmässigt parti.

Vid sidan av dessa illusionslösa inslag nagelfar romanens berättarröst statsledningen: åtgärderna mot svälten framställs som otillräckliga och där de vidtas, i form av nödhjälpsarbeten, drar man cyniskt nytta av krisen genom att halvera lönerna.

I en handbok från 1972 tolkar Johannes Salminen romanens kritiska ärende:

Sextiotalets hungerår stiger anklagande fram i Hårda tider (I89I), en uppgörelse med den nationella solidaritetsmyt som Runebergs bonde Paavo förkroppsligade. I sin roman vill Tavaststjerna visa "hur liten nöd det egentligen gick på de bildade klasserna”. Kapten Thoreld får

ingående studie av Barndomsvänner och dess plats i en litterär brytningstid, se Arne Toftegaard Pedersen, Det marginaliserede gennembrud. Tre moderne svensksprogede romaner fra I88oernes Finland, Åbo: Åbo Akademis förlag 2002, särskilt s. IO-78 och 208-27I.

5. Tavaststjerna, Hårda tider I89I, s. 205. 
illustrera denna tes bl.a. med den lysande middag han ger på sitt gods för huvudstadens notabiliteter, allt medan tiggarskarorna hungrigt storögda trängs framför de festupplysta fönstren. Här exponeras öppet ett hjärtlöst"tsaristiskt" överdåd hos landets överklass. ${ }^{6}$

De hårda tiderna är med andra ord ojämnt fördelade. Det insprängda citatet i Salminens text, om nöden och "de bildade klasserna", härstammar från Tavaststjernas försvarstal i Finsk Tidskrift sedan boken angripits från akademiskt håll. ${ }^{7}$ Tavaststjernas kritik av den "solidaritetsmyt" Salminen nämner passerade alltså inte utan skarpa mothugg.

Receptionen av Hårda tider har tidigare sammanfattats av bland andra Werner Söderhjelm (1900) och Pirkko Alhoniemi (1972). ${ }^{8}$ Nedan refererar jag mottagandet i något större detalj och följer upp med nedslag från hela I900-talet. Framställningen bygger på kritik och kommentarer i dags- och tidskriftspress, essäer, biografier och handböcker. ${ }^{9}$ Av utrymmesskäl begränsar jag mig, med några undantag, till receptionen på svenska i Finland. Avsikten är att genom ett längdsnitt belysa hur den kulturella-ideologiska institutionen i olika tider har förhållit sig till ett och samma verk. Viktiga brännpunkter blir de inslag av avidealisering, både öppen och implicit, som kan läsas in i verket. Hur har kritiker, forskare och en dramatiker reagerat på den "avförtrollning" som bedrivs i Hårda tider? ${ }^{10}$

6. Johannes Salminen, ”X. I860-I880: Finland”, Mogens Brøndsted (red.), Nordens litteratur efter 1860, København: Gyldendalske boghandel I972, s. I23.

7. Jag återkommer till försvaret längre fram i essän.

8. Werner Söderhjelm, Karl August Tavaststjerna. En levnadsteckning, Skrifter utgivna av Svenska litteratursällskapet i Finland XLVI, Helsingfors: Svenska litteratursällskapet i Finland I900, s. I93-200; Pirkko Alhoniemi, Idylli särkyy. Kansallisromanttisten ideaalien mureneminen jälkiromantiikan ja realismin kauden kirjallisuudessamme, Suomalaisen Kirjallisuuden Seuran toimituksia 305, Helsinki: Suomalaisen Kirjallisuuden Seura 1972, s. I27-I29; se också Erik Ekelund, Tavaststjerna och hans diktning, Skrifter utgivna av Svenska litteratursällskapet i Finland CCCXXXI, Helsingfors: Svenska litteratursällskapet i Finland 1950, s. 156-158.

9. Tidnings- och tidskriftsmaterial i Brages Pressarkiv, Helsingfors, samt i Nationalbibliotekets digitala tidningsdatabas, https://digi.kansalliskirjasto.fi/ collections? $\mathrm{id}=82$ \&set language $=$ sv.

Io. Mats-Peter Sundström har jämfört originalmanuskriptet till Hårda tider med den publicerade boken och visar att en del retuscheringar av troligen kontroversiella ordval har gjorts av författaren och/eller förlaget. Ändringar har enligt Sundström gjorts framför allt för "att icke låta motsättningarna mellan olika samhällsklasser 


\section{Den Första RECEPTIONEN (I89i)}

I dagspressen är de första reaktionerna på Hårda tider lovande: romanen făr huvudsakligen positiv kritik i huvudstadstidningarna Hufvudstadsbladet, Nya Pressen och Päivälehti. ${ }^{11}$ I Hufoudstadsbladet nämner signaturen A.B. inledningsvis

[...] det förhållandet, att de hårda tider, hvarom händelsen rör sig åter i den dag som är klappa sina tunga slag på mången dörr i vårt land, som allt sedan nödåret 1867 endast någon gång stått på glänt för den bleke gästen, men nu måste öppna sig på wid gafwel. ${ }^{12}$

Ämnet är alltså aktuellt, och som litterärt verk väcker romanen skribentens "tacksamhet". I den utförliga recensionstexten redovisas visserligen först en viss besvikelse över författarens analytiska hållning:

Tawaststjerna låter oss icke känna nödens fasta, oslippliga grepp i sitt offer, han låter oss icke lägga vårt öra lyssnande till hungerns torra, flämtande bröst, han endast konstaterar, som en skicklig läkare, de matta pulsslagen och den stoiska resignationen eller wisar oss huru brottet är hungerns barn med hatet. Hwad han berättar om nödens ravage hos enskilda personer tror man gerna och man förstår honom, men man lider icke med lidandet. Och förklaringen härtill kan delvis sökas deri, att de särskildt skildrade offren för hungersnöden dels äro

framstå såsom alltför accentuerade $\mathrm{i}$ texten och att undvika en alltför negativ karaktäristik av ståndspersoner". Till exempel har manuskriptets "den dryge herren med papegojansiktet" ändrats till "den säkra herren med örnnäsan" (s. I3 i originalutgåvan). Mats-Peter Sundström,"Blev Karl August Tavaststjernas roman 'Hårda tider' censurerad?", Marianne von Wright (red.), Struktur och variation. Festskrift till Bengt Loman 7.8.1983, Meddelanden från Stiftelsens för Åbo Akademi forskningsinstitut 85, Åbo: Åbo Akademi 1983, s. 153-167.

II. A.B., "Hårda tider. Berättelse från Finlands sista nödår. Karl A. Tavaststjerna", Hufvudstadsbladet 10/12 r89r; Arv. S, "Hårda tider. Berättelse från Finlands sista nödår. Karl A. Tavaststjerna", Nya Pressen Io/r2 I89r; [Osignerad recension],"Kotimaista kirjallisuutta", Päivälehti II/12 I89I.

I2. A.B. "Hårda tider". Notiser i dagstidningarna om insamlingar"till de nödlidande i landet" (till exempel Nya Pressen I5/12 I89I) bekräftar att nöden igen hotade landets eftersatta områden. 
sjelfförvållade dels icke ega karaktärer, som skulle stämma läsarens sympati fördelaktigt. ${ }^{13}$

Bristen på positiva hjältar som läsaren kunde identifiera sig med - "man lider icke med lidandet" - uppvägs för A.B. i alla fall klart av bokens kvaliteter: "Hwad han nu ger oss är så rikt och konstnärligt att man med öppna armar tar emot hans gåfwa". Romanen är ett "glänsande tragiskt tidspanorama". ${ }^{14}$

Bland de avsnitt som A.B. refererar finns romanens sarkastiska beskrivning av hur otillräckligt statsledningen reagerade på svälten:

På regeringens debetsida uppskrifvas underlåtenhetssynder, såsom att icke importera säd från utlandet i god tid och att besvara jordbrukarnes anhållan om tidiga åtgärder med en befallning till erkebiskopen att låta i alla landets kyrkor utlysa förböner för en god skörd. ${ }^{15}$

De kortare recensionerna i Nya Pressen, samma dag, och Päivälehti, följande dag, består till större delen av innehållsreferat och citat. Boken får också här lovord:"denna tid har aldrig förut skildrats så omfattande, sanningsenligt och konstnärligt" skriver Päivälehtis anonyma recensent. ${ }^{16}$ Intressant med tanke på den kommande debatten är att $N y a$ Pressens skribent Arv. S återger ett längre avsnitt från det panorama som i romanens tionde kapitel målas upp av ett frosthärjat Finland, sett ur den uppgående solens perspektiv:

Morgonens drottning vardt rörd af all den sorg hon blef vittne till, under det hon långsamt rullade upp dimmans ulltäcke från bygderna, och beslöt att så mycket det i hennes makt stod godtgöra köldens illgärningar. Men som en värklig drottning hade hon mera medkänsla än insikt i huru hon skulle bära sig åt, och hon tog sig bara för att lysa dubbelt mera bländande och varmt, så att de frusna sädesstån-

I3. A.B., "Hårda tider".

I4. Ibid.

I5. Ibid.

I6. "Mutta ei vielä koskaan ennen ole tätä aikaa kuvattu niin laajasti, kokonaisesti ja taiteellisesti.”, [Osignerad recension], "Kotimaista kirjallisuutta”. Översättning till svenska: TS. 
den hvitnade under hennes smekningar och potatisblasten begynte svartna och hänga skrumpen, sorgsen och ful mot jorden. [...] Men morgonens drottning stod så högt öfver altsammans, att hon trodde sig göra idel godt, och hela stora sträckor brände hon af på samma vis, öfvertygad om att hon utbredde himmelens välsignelse. ${ }^{17}$

Att solen har "mera medkänsla än insikt" kan ses som en metafor för bokens beskrivning av den tafatthet på myndighetshåll som också nämndes i Hufvudstadsbladets referat. En sådan tolkning antyds ändå inte av Arv. S och man kan också notera att till exempel festscenen i romanens "herrgårdsintrig"- som Johannes Salminen senare, 1972 skulle kalla "tsaristiskt överdåd" - inte berörs i någon av i8oo-talsrecensionerna.

Sådant är läget inför julmarknaden r8gr.

$$
\text { "BOKKRIGET" I } 892
$$

Det är i januari nästa år som det berömda "bokkriget" kring romanen inleds. De viktigaste angreppen på Hårda tider sammanfattas i efterskott, i mars 1892, i en redaktionell text i Huvfudstadsbladet:

Sedan den wäldige A.M. i Uusi Suometar serverat en serie polemiska artiklar mot Tawaststjernas skildring af nöden 1867, professorn i botanik Fr. Elfwing på Svenska litteratursällskapets årsmöte kallat ämnet i Hårda tider för tarfligt lättsinne och slutligen hr Ernst Gråsten främst på juridiska grunder uträknat författaren till Hårda tider wara en dilettant - utsätta wi oss måhända för löje genom att citera uttalanden af helt annan klang om samma bok af Georg Brandes, Karl Snoilsky och Werner v. Heidenstam. ${ }^{18}$

Tre kända nordiska författares positiva uttalanden om Hårda tider - i privata brev till författaren - citeras alltså i kontrast till tre njugga, till och med fientliga finländska kritikers omdömen. Först en blick på de senare.

I7. Arv. S, "Hårda tider". I originalet, Tavaststjerna, Hårda tider I891 s. I35-136.

I8. Red., "Tavaststjernas 'Hårda tider'.", Hufoudstadsbladet I3/3 I892, s. 2. 
”Den wäldige A.M.” är den på sin tid välkände lantdagsmannen och skribenten Agathon Meurman, starkt konservativ fennoman. ${ }^{19}$ Han publicerar sin långa artikelserie "Hungeråren på I86o-talet" för att tillbakavisa bilden av den dåvarande regeringens åtgärder i Hårda tider och ställa dem i bättre dager. Tavaststjernas bok är enligt Meurman grundad på "lösa, knorrande sqwallerhistorier". ${ }^{20}$

Fredrik Elfving, å sin sida, höll sitt föredrag "Naturen och våra diktare" på Svenska litteratursällskapet i Finlands Runebergsfest I892. Efter en utläggning om framför allt Runeberg och Topelius kommer slängen mot Tavaststjerna alldeles i slutet av det i tryckt form 20 sidor långa föredraget:

Äfven Tavaststjerna har skildrat hårda tider i vårt land, men han har icke känt något sammanhang mellan de små episoder han tecknat och det stora drama som 1867 i Finland spelades; de äro lösrykta scener ur ett hvardagsskådespel, bygdt på tarfligt lättsinne. ${ }^{21}$

Det tredje akademiska angreppet, Ernst Gråstens berömda, mycket negativa recension, publicerades i Finsk Tidskrifts februarinummer.

I9. Se Vesa Vares, "Meurman, Agathon", Biografiskt lexikon för Finland 2. Ryska tiden. Skrifter utgivna av Svenska litteratursällskapet i Finland 710:2, Helsingfors: Svenska litteratursällskapet i Finland 2009, s. 610-612. Meurman hade också riktat ett häftigt angrepp mot Minna Canths pjäs Työmiehen vaimo (1885, sv. Arbetarens hustru) ett annat naturalistiskt portalverk i finländsk litteratur. Se Alhoniemi, Idylli särkyy, s. 99.

20. A.M. [Agathon Meurman], Hungeråren på I860-talet, Folkupplysningssällskapets skrifter 78, Helsingfors: Folkupplysningssällskapet I892, s. 4. Original:"Nälkävuodet I86o-luvulla", artikelserie i Uusi Suometar I892. Även utgiven i Kansanvalistusseuran julkaisut 78, 1892. Se även Heidi Hirvonen, Tiedon, tahdon vai resurssien puutetta? Suomen hallinto ja syksyn I867 elintarvikekriisi, avhandling pro gradu, Helsingfors universitet 2013, s. I5, http://urn.fi/URN:NBN:fi:hulib-201703272348 (hämtad 27/II 2020).

2I. Fredrik Elfving, ”Naturen och våra diktare. Föredrag vid årsmötet den 5 februari I892", Förhandlingar och uppsatser 6, Skrifter utgivna av Svenska litteratursällskapet i Finland XX, Helsingfors: Svenska litteratursällskapet i Finland I892, s. I20, https://archive.org/details/frhandlingarochoofinlgoog/page/n238/ (hämtad 2I/5 202I). Enligt referatet "Svenska literatursällskapet" i Hufvudstadsbladet 6/2 I892 (omtryckt i landsortsupplagan 7/2 I892) mottogs föredraget "med applåder af den i solennitetssalen talrikt församlade publiken". (Samma text: "Hemlandet", Åbo Underrättelser 7/2 1892). Tavaststjerna protesterade i ett kort genmäle, "Några öppna rader till docenten Fredr. Elfving.", Hufvudstadsbladet 9/2 1892, mot uttalandet som han kallade "långt mera taktlöst än karaktäriserande". 
Gråsten påtalar en mängd sakfel, språkfel och stilfel han ser i romanen, som enligt honom är"lättvindigt konstruerad och därtill tendentiös". ${ }^{22}$ Vidare ser Gråsten felaktigheter i romanens komposition - morddramat borde enligt honom ha fătt mindre utrymme, mera borde $\mathrm{i}$ stället ha getts den positivt skildrade herrskapsfrun von Blume (som efter att ha organiserat bespisning och sjukvård smittas av de hungrande och dör i tyfus). Inte heller den psykologiska gestaltningen övertygar honom; mördaren Lehtimaas "blödsinne" (vekhet) verkar enligt Gråsten påklistrat. Gråsten spekulerar i fallet Lehtimaa till och med kring skrivprocessen: Tavaststjerna har "midt i berättelsen kommit på andra tankar" och tvingats att "sent omsider anbringa en retouche på karaktären." 23

I sitt lika berömda "sjelfförsvar", som ingick i följande nummer av Finsk Tidskrift, förbigår Tavaststjerna de litterära synpunkterna. Liksom i klippen i Hufoudstadsbladet ur hyllande brev från nordiska kolleger, ironiserar Tavaststjerna i Finsk Tidskrift över kritikernas enligt honom helt utomlitterära angreppsvinklar: ”Jag hoppas åtminstone kunna ställa min bok i en mera rent skönlitterär dager, än mina vedersakare velat eller förmått kasta öfver den”. ${ }^{24}$

Något demagogiskt hade både Meurman och Gråsten kritiserat Tavaststjerna för att se på samhället uppifrån och neråt i stället för tvärtom, ur de lidande massornas synvinkel. ${ }^{25}$ Tavaststjerna turnerar med att just detta är det nya och originella i hans roman. Mycket ofta citerad är formuleringen av hans program: han har på det sättet velat "visa, hur liten nöd det egentligen gick på de bildade klasserna. Ty dessa ha under tidernas lopp tämligen oberättigadt begynt tillämpa på sig själva Runebergs rent folkliga Paavomyt". ${ }^{26}$

I den snärten ligger en skarp ideologisk iakttagelse om den runebergska mytens funktion som verklighetsflykt för överklassen. Ett tema som egentligen ingen kommentator riktigt hakar på under förra delen av igoo-talet.

22. Ernst Gråsten, ”Tavaststjernas 'Hårda tider”, Finsk Tidskrift I892:2, s. I5I.

23. Ibid., s. I59.

24. K.A. Tavaststjerna, "'Hårda tider'. Sjelfförsvar", Finsk Tidskrift ı892:3, s. 227. Se också Ernst Gråsten, "Genmäle", Finsk Tidskrift I892:4, s. 366-367.

25. Meurman, "Nälkävuodet", s. 5; Gråsten, "Tavaststjernas 'Hårda tider", s. I57.

26. Tavaststjerna, "'Hårda tider'. Sjelfförsvar", s. 228. 
"Sjelfförsvaret" återges till stora delar i Werner Söderhjelms Tavaststjernabiografi (I900) ${ }^{27}$ och i företalen till nyutgåvorna av Hårda tider I924 och I96r. Det framstår alltså där i viss mening som en del av själva romanen. I nyutgåvan I99I (omtryckt 2004) saknas självförsvaret. ${ }^{28}$

De tre kända författare som uppbådas av författaren bakom försvarsartikeln i Hufvudstadsbladet, som kontrast till Meurmans, Elfvings och Gråstens attacker, betecknas i artikeln som "nordens skarpsinnigaste kritiker","Sveriges nu lefwande främste skald" samt "dess originellaste yngre författare". Det handlar om brev som redaktionen "på begäran erhållit af hr Tavaststjerna".

Hårda tider är enligt Georg Brandes brev"en riktigt god bok och det bästa ni ännu har skrifvit". Också Carl Snoilsky kallar den "höjdpunkten af din hittilsvarande produktion". Verner von Heidenstam, slutligen, jämför inte enbart med Tavaststjernas tidigare produktion utan kalibrerar romanen i ett nordiskt sammanhang: enligt honom är Tavaststjernas Hårda tider, Oscar Levertins Legender och visor, Arne Garborgs Trötta män och Selma Lagerlöfs Gösta Berlings saga "utan twifwel denna winters förnämsta och som jag tänker mest waraktiga literära alster" ${ }^{29}$

\section{IN I I 900-TALET}

Den samtida, så att säga "klassiska" receptionen av Hårda tider avrundas med Werner Söderhjelms levnadsteckning som utkommer 1900, två år efter Tavaststjernas död. Söderhjelm ägnar i sin bok ett relativt stort utrymme åt romanen och i synnerhet åt debatten kring den. Själv är han bara delvis entusiastisk över den förra; han tilltalas inte av Tavaststjernas ironiska tonfall och önskar mer av patos och "episk kraft". Han motsätter sig visserligen Gråstens och Elfvings uppfattning att handlingen i romanen inte förutsätter ett nödår, men anser samtidigt att uppbyggnaden saknar jämvikt och proportion mellan de olika planen. Beträffande mordhistoriens trovärdighet frågar han om

27. Werner Söderhjelm, Karl August Tavaststjerna. En lefnadsteckning 1900, s. I95-198. Även i Werner Söderhjelm, Karl August Tavaststjerna. En levnadsteckning. Andra, genomsedda upplagan, Helsingfors: Victor Hoving I9I3, s. 222-225.

28. Se not 34 för en förteckning över olika utgåvor.

29. Red.,"Tavaststjernas 'Hårda tider"'. 
den månne inte är en lika typisk följd av hungersnöden som bonden Paavos historia. ${ }^{30}$

Söderhjelm vacklar alltså mellan ett "äldre" och ett" nyare" synsätt på folket och på litteraturens uppgift. Karakteristiskt är att han avslutar med en hymn till den ovan citerade frostnattsscenen i boken ("Morgonens drottning vardt rörd ...") - över huvud taget lovordar de flesta tidiga kritikerna just naturskildringarna.

Parallell med Söderhjelms bedömning är I.A. Heikels sammanfattning i Finsk biografisk handbok (1903):

Strängt bedömt af kritiken här hemma, mot hvilken [Tavaststjerna] ansåg sig själf böra uppträda, innehåller arbetet emellertid, äfven om de riktiga proportionerna saknas och en del historiska misstag äro begångna, gripande teckningar från nödårets dagar. ${ }^{31}$

När den finska utgåvan Kovina aikoina publiceras våren I892, i Juhani Ahos översättning, ${ }^{32}$ passar Päivälehti på att försvara romanen mot de svenskspråkiga akademikernas angrepp. En intressant detalj som här framgår är att Tavaststjerna sägs ha strukit "felaktigheter" i den finska versionen: "Sådan den nu presenteras för finska läsare torde där inte finnas något, som kunde kallas oskälig kritik av regeringens män”. ${ }^{33}$ Såtillvida lyckades Meurman och Gråsten tydligen med sina bredsidor få Tavaststjerna att ta udden av en del kritik. Särskilt I96o- och 7o-talen har, som vi ska se, gett originalversionen ett slags upprättelse.

Ur receptionssynpunkt, och som ett mått på romanens klassikerstatus, kan man notera att nya finska utgåvor av romanen utkom 1960, I975 och 1983. Norska och danska översättningar utkom I893,

30. Söderhjelm, Karl August Tavaststjerna I900, s. 20I-206.

3I. I.A. Heikel, "Tavaststjerna, Karl August", Tor Carpelan (utg.), Finsk biografisk handbok. Under medvärkan af fackmän, Helsingfors: Edlunds I903, s. 2I77.

32. Karl A. Tavaststjerna, Kovina aikoina: kertomus Suomen viimeisten nälkävuosien ajoilta. Suomensi Juhani Aho, Porvoo: Werner Söderström I892.

33. "Sellaisena kuin se nyt tarjoutuu suomalaisille lukijoille ei siinä liene mitään, jota voisi sanoa hallitusmiesten kohtuuttomaksi moittimiseksi." Översättning till svenska: TS. [Osignerad],"Kirjallisuutta”, Päivälehti I8/3 I892. I maj kritiserar tidningen Meurmans motskrift Nälkävuodet I860-luvulla [sv. utgåva Hungeråren på I860-talet] för att inte beakta dessa förändringar i den finska utgåvan. [Osignerad], ”Nälkävuosikirjallisuutta", Päivälehti 28/5 I892. 
tyska I948 och I983. På svenska gavs romanen ut på nytt i tryckt form I9I4, I924, I96I och I99I, den sistnämnda omtryckt 2004. I dag finns digitala versioner fritt tillgängliga på nätet på svenska och finska. ${ }^{34}$

\section{Tystnad. Perioden i 904-I947}

Kännetecknande för följande period inom Tavaststjernareceptionen är att den är relativt ointresserad av Hårda tider. Detta trots att boken utkommer på nytt två gånger på svenska: I9I4 självständigt ${ }^{35}, 1924$ som del av en utgåva av Tavaststjernas samlade skrifter. ${ }^{36}$ Några korta anmälningar av dessa samt en något längre artikel i Wasa Posten I9I4 tycks vara de påminnelser om romanens existens som dagstidningsläsarna får under 40 års tid. ${ }^{37}$ Artikeln, av signaturen -t-, granskar "novellens" starka och svaga sidor enligt ungefär samma linjer som

34. K.A.Tavaststjerna, Kovina aikoina: kertomus Suomen viimeisten nälkävuosien ajoilta, Porvoo: WSOY I96o; K.A. Tavaststjerna, Valitut teokset: Lapsuudenystävät, Kovina aikoina, Pikku Karl, Hämeenlinna: Karisto I975; K.A. Tavaststjerna, Kovina aikoina: Pikku Karl, Suomalainen sarja 4, Hämeenlinna: Karisto I983. I892 års finska utgåva har digitaliserats i Projekti Lönnrot, http://www.lonnrot.net/kirjat/o5go.zip (hämtad 29/4 202I); K.A. Tavaststjerna, Haarde tider. Fortelling fra Finlands sidste nødaar, oversat af K.V. Hammer, Kristiania: Aschehoug I893; K.A. Tavaststjerna, Strange Tider. Fortalling fra Finlands sidste Nødaar, autoriseret Oversættelse ved Peter Nansen, København: Gyldendal 1893 (ny utgåva 1907); K.A. Tavaststjerna, Harte Zeiten, übers. Heinz Küpper, Kempen-Niederrhein: Thomas-Verlag I948; Harte Zeiten, übers. Klaus-Jürgen Liedtke, Sammlung Trajekt I4, Helsinki: Otava I983. Efter originalutgåvan I89I har romanen publicerats fem gånger i tryck på svenska: K.A. Tavaststjerna, Hårda tider, Helsingfors: Schildts I9I4 (även Stockholm: Bonniers); K.A. Tavaststjerna, Hårda tider; Lille Karl, Samlade skrifter 5, Helsingfors: Schildts I924; K.A. Tavaststjerna, Hårda tider, Finlandssvenskt bibliotek I7, Helsingfors: Söderström I96r; K.A. Tavaststjerna, Hårda tider, Nya klassikerserien, Helsingfors: Söderströms I99I, omtryckt 2004. Digitaliserade utgåvor av originalutgåvan I89I via åtminstone Nationalbiblioteket, https://www.doria.fi/bitstream/ handle/10024/100393/H rda tider berattelse fr n Fi.pdf och Göteborgs Universitet, URI: http://hdl.handle.net/2077/40I44; av I925 års utgåva i Projekt Runeberg, http://runeberg.org/kathtid/; av norska utgåvan 1993 Nasjonalbiblioteket, https:// www.nb.no/items/4I75ec7dIf523e5327037cerddaof338 (hämtade 29/4 202I).

35. Tavaststjerna, Hårda tider I9I4.

36. Tavaststjerna, Hårda tider; Lille Karl.

37. O.E. [Olof Enckell],"K.A. Tavaststjerna första gången i samlad upplaga”, Hufvudstadsbladet 2/II I924; G.C. [Gunnar Castrén], "Tavaststjernas skrifter", Nya Argus I924:20; R.G-t. [Ragnar Granit], "Tavaststjernas samlade arbeten", Studentbladet 23/II I925; -t-, "Nya böcker.", Wasa Posten I6/I2 I9I4. 
Söderhjelm, men pekar inledningsvis ut några ideologiska orsaker till kritiken vid utgivningen:

Då Tawaststiernas alster öwerhuwud ej genomgås aw den fosterländska patos, som warit det utmärkande draget $i$ wår tidigare diktning och författaren i denna sin första skildring aw det finska bondeliwet icke presenterat några idealtyper, bör det ej wäcka förvåning, att arbetet wid sitt första framträdande på en del håll emottogs tämligen kyligt. ${ }^{38}$

Tre år senare, I9I7, ingår tre citat ur Hårda tider - utan direkt angivande av källan - i Edvard Gyllings analys av svältkatastrofen r867-68. I hans uppsats i den socialdemokratiska årsskriften Työväen kalenteri I9I $8^{39}$ används romancitaten för att beskriva svältens verkningar och regeringens overksamhet. Vidare visar Gylling med stöd i statistiska uppgifter att kapitalstarka spekulanter drog nytta av nödläget, till exempel genom att köpa upp överbelånade hemman billigt, och att också regeringen utnyttjade situationen, till exempel vid järnvägsbygget mellan Helsingfors och S:t Petersburg. ${ }^{40}$ Intressant nog citeras inte de passager i Hårda tider där Tavaststjerna med bitter sarkasm kommenterar detta, till exempel:

Järnvägsbyggnadsstyrelsen antog arbetare i hundratal, i tusental. Men en järnvägsbyggnad är ingen barmhärtighetsinrättning, man hade icke beredt sig på tillströmningen af folk, man var ekonom av princip och man begynte spekulera i arbetslöshet. Lönerna gingo ner till hälften, - det fans ledigt folk öfvernog, och det kom alt mer. Järnvägsbyggnadsstyrelsen bestod af tekniskt bildade, som icke sysslat med nationalekonomi och sociala spörjsmål. Den hade endast en uppgift: att bygga banan färdig så billig som möjligt. Och mången av dess ledande män kunde icke förneka att de kände sig ganska glada

38. -t-, "Nya böcker".

39. E[dvard] Gylling,"Nälkävuodet I867-68. Puolivuosisataismuisto", Työväen kalenteri XI I9I8 [sv. "Hungeråren 1867-68. Ett halvsekelminne.", Arbetarnas kalender] Sosialidemokratisen [sic] puoluetoimikunnan julkaisema, Helsinki I9I7, s. IIO-I2I. Som källa till det första citatet anges "eräs suomalainen kirjailija" (sv."en finländsk författare", s. II2), för det andra "eräs porvarillinen kaunokirjailija" (sv."en borgerlig skönlitterär författare”, s. II8).

40. Gylling, "Nälkävuodet I867-68”, s. II4 
när — tack vare hungerkonjunkturerna - de låga arbetslönerna lofvade sänka hela byggnadens totalbudget med någon million under det urpsungliga [sic] kostnadsförslaget. Det kunde man kalla en god ekonomisk förvaltning, som för alltid skulle stå såsom ett exempel i Finlands järnvägsbyggnadshistoria. ${ }^{41}$

Tavaststjerna å sin sida hade kanske inte, när han skrev Hårda tider, tillgång till fakta till exempel om exporten av brödsäd från Finland. Enligt Gylling var denna lika stor eller till och med större under svältåren, medan exporten av smör ska ha två- till tredubblats. ${ }^{42}$

I litteraturhistorieböckernas och -översikternas värld lever romanen under I900-talets första hälft, även om förtur i presentationerna av Tavaststjernas verk i allmänhet ges hans poesi. Symptomatiskt är att Erik Kihlmans monografi Tavaststjernas diktning (1926) ägnar jämnt en av 368 sidor åt Hårda tider, och mycket mer utrymme åt hans övriga prosaverk. ${ }^{43}$ Också Arvid Mörnes två uppsatser om Tavaststjerna (I898 och 1939) - båda enbart om lyriken - kan ses som en intressant frånvaro. ${ }^{44}$

I en notis i Arbetarbladet 1935 frågar sig signaturen "polypen"(Elmer Diktonius) hur det kommer sig att det är så tyst kring Tavaststjernas 75-årsdag:

[...] hur det är och då man närmare överblickar våra svenska klassikers snyggttråkiga skara, är nog Tavaststjerna den som står i tätaste kontakt med den moderna diktande ungdomen av i dag. ${ }^{45}$

4I. Tavaststjerna, Hårda tider I89I, s. I40-I4I. Även:"Järnvägsbyggnadsstyrelsen byggde långa mil färdiga långt under medelpris $[\ldots]$ ", s. I55.

42. Gylling, "Nälkävuodet I867-68", s. II9-I2O.

43. Erik Kihlman, Karl August Tavaststiernas diktning, Skrifter utgivna av Svenska litteratursällskapet i Finland CLXXXVIII, Helsingfors: Svenska litteratursällskapet i Finland 1926, s. 224.

44. Arvid Mörne, "Karl August Tavaststjerna”, Ord och Bild 1898:5, Stockholm: P.A. Norstedt \& Söner, s. 225-228; Arvid Mörne, "Tavaststjerna, Jonatan Reuter och skärgårdslyriken”, Arvid Mörne, Lyriker och berättare: finlandssvenska studier, Skrifter utgivna av Svenska litteratursällskapet i Finland CCLXXVI, Helsingfors: Svenska litteratursällskapet i Finland 1939.

45. polypen, Arbetarbladet 24/5 1935 . 
Längre än så utvecklar Diktonius tyvärr inte temat. ${ }^{46}$ Allmänt kan man konstatera att 1930- och största delen av 1940-talet är dåliga tider också för Hårda tider.

Före 1930 hinner romanen i alla fall bli omnämnd i minst fem litteraturhistoriska översikter och studier, förutom Erik Kihlmans. Och i omdömena tränger faktiskt ett par nya toner in.

I den första översikten, Gunnar Castréns korta inledning I9II till andra delen av det tjugofemte bandet av Sveriges national-litteratur, under titeln "Finländsk litteratur utom Runeberg", markeras redan en viss distans till idealismen: Tavaststjerna skyr enligt Castrén inte att "låta det finska folket framträda i ett hårdare, obarmhärtigare ljus än det ideala skimmer traditionen kräfde". ${ }^{47}$ Det är ett sätt att tala om "traditionen" som jag inte stött på tidigare i mitt material.

I Ruth Hedvalls Finlands svenska litteratur från I9I7 tas redan öppet ställning:"Av den traditionella alltfor idealistiska uppfattningen av det finska folket finnes det i denna bok intet spår" (min emfas). ${ }^{48}$ Och i Bertel Appelbergs skolbok I92I nämns att"den traditionella uppfattningen" är "från Runebergs tid". ${ }^{49}$

Den här förskjutningen - som kanske fullbordas I935 när Yrjö Hirn använder begreppet"Runebergskulten" som boktitel ${ }^{50}$ - föregrips förstås av Tavaststjernas egen, ofta citerade satir i "sjelfförsvaret" 1892 , över"den gamla penalismens [sic] dunkande med knogarna i bordet och dess drastiska, stora vishetsregel: Skrif som Runeberg, gossar, så

46. I ett brev 29/7 I930 till den rikssvenske professorn och litteraturkritikern John Landqvist nämner Diktonius Gustaf "Guss" Mattsson som "en av de få verkliga européer vi frambragt - till dem räknar jag bara Albert Edelfelt och Tavaststjerna". Jörn Donner \& Marit Lindqvist (utg.), Elmer Diktonius brev, Skrifter utgivna av Svenska litteratursällskapet i Finland 595, Helsingfors: Svenska litteratursällskapet i Finland I995, s. I84.

47. Gunnar Castrén, "Finländsk litteratur utom Runeberg. Stenbäck. Topelius. von Qvanten. Wecksell. Tavaststjerna. Lybeck.", Sveriges national-litteratur [sic] I5OOI900 XXV:2, Stockholm: Bonniers I9II, s. I7, https://archive.org/details/sveriges national25p2stoc (hämtad 24/5 202I).

48. Ruth Hedvall, Finlands svenska litteratur, Skrifter utgivna av Åbo akademikommitté 5, Borgå: Schildts I9I7, s. 267, http://urn.fi/URN:NBN:fi-fd20I7-000I4002 (hämtad 24/5 202I). Även Stockholm: Björk \& Börjesson I9I8.

49. Bertel Appelberg, Svensk litteraturbistoria för lärdomsskolor, Helsingfors: Söderström \& Co I921, s. I27.

50. Yrjö Hirn, Runebergskulten, Skrifter utgivna av Svenska litteratursällskapet i Finland 248, Helsingfors: Svenska litteratursällskapet i Finland 1935. 
skrifver ni bra!". ${ }^{51}$ Men det är betydelsefullt att hans synsätt faktiskt småningom övertas också av litteraturhistorikerna - visserligen med 20-40 års fördröjning.

\section{Är LehtimaA en Aapo?}

John Landqvists Modern svensk litteratur i Finland (1929) introducerar en ny klangbotten till läsningen av Hårda tider: den "bildade klassens" chock över inbördeskriget I9I8. Om romangestalten Lehtimaa skriver han:

I sin grova okunnighet, sin bristande uppfattning av reala sammanhang, sin lättrörda inbillning vars fantasier fylla honom så att de leda hans handlingar, slutligen ända fram till dubbelmord, skulle han, som han går och står, kunna insättas som en av komparserna i röda upproret, en frände till Runar Schildts Aapo. Barbaren Lehtimaas slöa verklighetsuppfattning och intensiva fantasiliv är samma karaktärsart, som i annan tid gör det slag av farliga utopister och drömmare, som gå rakt på den blodiga gärningen. Överensstämmelsen mellan Lehtimaa och en del av det röda upprorets psykologi bevisar, med vilken klarhet Tavaststjerna i Lehtimaa uppfattat ett drag i det finska folklynnet. Jämför man Lehtimaa med bonden Paavo, den dittills i den allmänna åskådningen och i litteraturen dominerande typen av den finska bonden, så ser man vidden och vikten av den nyhet, som Tavaststjernas medvetna realism innebar. ${ }^{52}$

En version av detta det psykologiserade röda upproret finns också i Johannes Salminens artikel i Hufoudstadsbladet I960, omtryckt i hans essäbok 1963. Han kallar där Lehtimaa "en olycksbådande finsk Caliban som rusar fram ur de djupa skogarnas natt. Mordet i Uramo torp var mer än en pittoresk anekdot, det var en varning som aldrig i tid hann fram". ${ }^{53}$

51. Tavaststjerna, "'Hårda tider'. Sjelfförsvar", s. 228.

52. John Landqvist, Modern svensk litteratur i Finland, Helsingfors: Söderström I929, s. $48-49$.

53. Johannes Salminen, "Karl August Tavaststjerna", Hufvudstadsbladet I3/5 I960; Johannes Salminen, Levande och död tradition, Helsingfors: Söderström I963, s. 36 . 
Revolutionsförsöket I9I8 anses här bekräfta ett brutalt "drag i det finska folklynnet", som Tavaststjerna med diktarens klarsyn skulle ha lagt i dagen. Snarare än som till exempel en del av en internationell politisk rörelse, eller som inspirerad av den bolsjevikiska statskuppen i S:t Petersburg året innan.

Landqvists och Salminens tolkning kan ses som ett oväntat exempel på den naturalistiska mänskoskildringens användbarhet i den ideologiska kampen: med enskilda gestalter ur litteraturen som "bevis" kan hela folk och samhällsklasser framställas som primitiva och opålitliga. Samtidigt blir detta bruk av romanen en aktualisering och anknytning till en för skribenterna och publiken mera närliggande verklighet, på samma sätt som A.B.i sin recension i Hufoudstadsbladet I89I anknöt till en då på nytt hotande hungersnöd.

\section{"Socialt intresse": Perioden I948-ig8I}

Följande fas, början till ett nytt uppsving för Hårda tider-intresset, inträder kring 1950 med en artikel i Hufoudstadsbladet om Tavaststjerna I948 och en ny monografi I950. Båda är skrivna av Erik Ekelund och i den senare finns för första gången en utförlig, systematisk innehållsanalys av romanen - som nu alltså har nästan 60 år på nacken. ${ }^{54}$

Också Gunnar Castrén ägnar ett proportionellt sett större utrymme åt romanen i sin artikel för $N y$ illustrerad svensk litteraturbistoria (I957) än han gjort i tidigare sammanhang, I9II och I924. ${ }^{55}$

Karakteristiskt för 5o-talsuppsvinget - om man kan säga att två studier gör en sommar - är att uttryck som "starkt socialt intresse" (Ekelund) ${ }^{56}$ och "demokratisk tendens" (Castrén) börjar användas av etablerade litteraturforskare i samband med romanen. Enligt Gunnar

54. Erik Ekelund, "Den ensamme Tavaststjerna", Hufvudstadsbladet 28/3 I948; Erik Ekelund, Tavaststjerna och hans diktning, Skrifter utgivna av Svenska litteratursällskapet i Finland CCCXXXI, Helsingfors: Svenska litteratursällskapet i Finland I950, s. I40-I56.

55. Gunnar Castrén, "Finländsk litteratur utom Runeberg”; G.C. [Gunnar Castrén]; "Tavaststjernas skrifter", Nya Argus I924:20, s. 248-250; Gunnar Castrén, "Karl A. Tavaststjerna", Eugène Napoleon Tigerstedt (red.), Ny illustrerad svensk litteraturbistoria 4: Attiotal. Nittiotal, Stockholm: Natur och kultur 1957.

56. Ekelund, "Den ensamme Tavaststjerna". 
Castrén hör romanen till"den svenskspråkiga och nordiska realismens bästa skapelser". ${ }^{57}$

Erik Ekelund introducerar ett nytt och tydligare språkbruk: han skriver om " motsättningen mellan överklassens liv och den bottenlösa misär som den besittningslösa befolkningen får utstå" - under i89o-talet talade till exempel A.B. i Hufvudstadsbladet om en "kontrast" ${ }^{58}$ Tavaststjernas ironier och satir hade upprört fiender som Gråsten I892, men föll inte heller Tavaststjernas biograf Söderhjelm I900 på läppen och litteraturhistorikern Ruth Hedvall beskrev I9I7 tonfallet som "nonchalans, nästan snobbism". ${ }^{59}$ Med Ekelund börjar detta drag tvärtom uppskattas och det blir med tiden ett huvudtema i receptionen. Till exempel Riikka Rossi nämner i en studie 2020 ironin som romanens "centrala trop" ${ }^{60}$

Erik Ekelund påpekar bland annat den ironiska biton som själva romantiteln får om man ställer den mot huvudmotivet, som (åtminstone enligt Tavaststjernas "självförsvar") är överklassens rätt oberörda liv under hungerkatastrofen. ${ }^{61}$ En ännu mera central observation i Ekelunds närläsning är den kontrast författaren skapar, i kapitlet om "Morgonens drottning", mellan en topeliansk form och ett illusionslöst naturalistiskt innehåll:

Diktaren visar hur naturen inte bryr sig det bittersta om mänskornas önskningar och lidanden. Hela stora sträckor bränner solen av, "övertygad om att hon utbredde himmelens välsignelse" - heter det med en ironisk hänsyftning på de av ärkebiskopen påbjudna bönerna till den Högste om en god skörd. Det är naturens svar på dem - det finns ingen annan som svarar. Bilden av solen gömmer formellt på en reflex av personifikationerna i Topelius' sagor, men reellt på den mest illusionslösa naturalism. Det ohyggliga som sker framträder

57. Castrén, "Karl A. Tavaststjerna", s. 356, 365, 374 .

58. Ekelund, "Den ensamme Tavaststjerna". (Min kursivering); A.B., "Hårda tider".

59. Gråsten,"Tavaststjernas 'Hårda tider"; Söderhjelm, Karl August Tavaststjerna I9oo; Hedvall, Finlands svenska litteratur, s. 267.

6o. "[...] Hårda tider -romaanin keskeinen trooppi, ironia [...]”. Riikka Rossi:"Nälkävuosien tunnehallinto, Z. Topeliuksen 'Septembernatten' (I867) ja K.A. Tavaststjernan Hårda tider (I89I)", Joutsen / Svanen. Erikoisjulkaisuja 2020:4, s. 22, https:// doi.org/IO.33347/jses.86974 (hämtad I7/4 2021).

6r. Ekelund, Tavaststjerna och hans diktning, s. I42; Tavaststjerna,"'Hårda tider'. Sjelfförsvar", s. 228. 
mera brutalt än någonsin genom att de indifferenta naturföreteelserna i förmänskligad gestalt ställes jämsides med de mänskliga förhoppningar, som så grymt svikes genom dem. ${ }^{62}$

1960 har det förflutit roo år sedan Tavaststjernas födelse, och Erik Ekelunds nya betoning av den sociala kritiken i Hårda tider går igen i minnesartiklar, till exempel i Johannes Salminens ovan citerade essä i Hufrudstadsbladet. ${ }^{63} \mathrm{I}$ sin essä om finlandssvensk litteratur i Bonniers Litterära Magasin I960 nämner Jörn Donner Hårda tider, Tavaststjernas "bästa roman" som "ett utslag av naturalismens latenta antikapitalism". ${ }^{64}$ Och i sin anmälan i Abo Underrättelser I96I av "folkupplagan" av Hårda tider i bokserien Finlandssvenskt bibliotek ${ }^{65}$ kallar Ole Torvalds den "en spänstig föregångare till vår tids sociala roman" ${ }^{66}$ Kritiken av myndigheternas handfallenhet ${ }^{67}$ och "de bildade klassernas" ihåliga tillämpande av"Runebergs rent folkliga Paavomyt" på sig själva, som Tavaststjerna uttryckte det ${ }^{68}$ är tillbaka på scenen. ${ }^{69}$

62. Ekelund, Tavaststjerna och hans diktning, s. I48; jfr Tavaststjerna, Hårda tider I89I, s. I33-I39. Trots en noggrann analys av ironiska element i Hårda tider observerar Riikka Rossi inte - i motsats till Ekelund - Tavaststjernas utspel av form mot innehåll i detta romankapitel. Se Rossi, "Nälkävuosien tunnehallinto”.

63. Trots att Salminen i likhet med Ekelund lyfter fram romanens kritiska ärende, är Hårda tider enligt honom "minst av allt en social indignationsroman. Tonen är kall, osentimental, och perspektivet hela tiden 'herrskapets". Salminen, Levande och död tradition, s. 36.

64. Jörn Donner,"Den finlandssvenska skepnadens riddare”, Bonniers Litterära Magasin I96o:2, S. I26-I27.

65. Tavaststjerna, Hårda tider, I96r.

66. Ole Torvalds, "En spänstig föregångare till vår sociala roman”, Åbo Underrättelser $25 / 2$ I961.

67. "Senatens åtgärder för att lätta situationen var enligt nutida synsätt oförlåtligt otillräckliga". Carl Michael Runeberg, Finlands historia, Helsingfors: Söderström \& Co r97.

68. Tavaststjerna, "'Hårda tider'. Sjelfförsvar", s. 228.

69. Se t.ex. Johan Wrede, "Karl August Tavaststjerna”, Lars Lönnroth \& Sven Delblanc (red.), Den Svenska Litteraturen: De liberala genombrotten I830-I890, Stockholm: Bonniers I988, s. I97; Johan Wrede, "K. A. Tavaststjerna - den hårda verkligheten", Johan Wrede (utg.), Finlands svenska litteraturhistoria. Första delen: Åren I400-I900, Helsingfors: Svenska litteratursällskapet i Finland \& Stockholm: Atlantis I999, s. 443 . 


\section{EN BRA STORY OM DEN FINSKA KAPITALISMENS \\ UPPKOMST: HÅRDA TIDER PÅ SCENEN}

Redan 1892 dramatiserades morddramat som ingår i Hårda tider av författaren själv i samarbete med Juhani Aho. Enligt den senare ska Tavaststjerna ha förklarat att han valt att publicera pjäsen på finska "därför att Svenska teatern inte visade samma intresse för inhemska stycken, särskilt allmogepjäser, som Finska teatern". ${ }^{70}$ Pjäsen, Uramon torppa (sv. Uramo torp), hade premiär på Finska teatern i Helsingfors I oktober I892 och enligt Werner Söderhjelm var"framgången mycket stor" ${ }^{\prime 1}$. På svenska gick pjäsen inte upp förrän r898, i februari i Björneborg och i april i Helsingfors. ${ }^{72}$ Under mellantiden dog Tavaststjerna. Om helsingforspremiären skriver Söderhjelm:"Men äfven när stycket efter författarens död uppfördes af Ahlboms teatersällskap på svenska, värkade det synnerligen väl. / Tidningarna voro fulla af loford" ${ }^{73}$

I974 får romanen en nytändning på scenen: Hårda tider sätts upp på Svenska Teatern i Helsingfors och på Wasa Teater, i dramatisering och regi av Bengt Ahlfors. Det handlar här om en nyskriven pjäs som utgår från hela romanen. Av intresse för vår receptionsstudie är Ahlfors essä kring sin arbetsprocess, ”Dagbok med Tavaststjerna” (I980). Ahlfors skriver att han hade haft lust till detta projekt sedan i965: "Kärlek, våld, bedrägeri, starka mänskliga lidelser. En bra story." ${ }^{\prime 4}$ Men han upplever under arbetet med pjäsen också avståndet till texten:

Som ju fängslar som utmaning, idé. Men vars problemkomplex inte ligger mig nära. Ifall jag inte kan erövra det, upptäcka de för mig viktiga frågorna $[\ldots]$.

Vad är idén med att berätta såhär gamla historier? Kan man på

70. Ekelund, Tavaststjerna och hans diktning, s. I59.

71. Söderhjelm, Karl August Tavaststjerna 1900, s. 221.

72. "I Helsingfors har stycket aldrig uppförts på svenska språket. Kort före sin död hade författaren tillfälle att i Björneborg öfvervara flere repetitioner samt pjäsens premiére därstädes." Notis, "Alexandersteatern" i Hufoudstadsbladet 20/4 I898.

73. Söderhjelm, Karl August Tavaststjerna I900, s. 224. På svenska publicerades pjäsen i K.A. Tavaststjerna, Samlade skrifter. Band 4, Helsingfors: Schildts I924.

74. Bengt Ahlfors, "Dagbok med Tavaststjerna”, Merete Mazzarella et al. (red.), Författare om författare. 24 finlandssvenska diktarporträtt, Helsingfors: Söderström \& Co r 980 , s. 39 . 
detta vis berätta om den finska kapitalismens uppkomst och är det viktigt att göra det idag? ${ }^{75}$

Ahlfors läser sidan 55 i romanen - den om hur"kapitalisterna - bland dem främst regeringen" - aldrig haft bättre finanser, om hur stora firmor i kuststäderna kunde göra "glänsande spekulationer i landets nöd", medan regeringen:

föredrog den passiva rollen af de aktiva spekulanternas mäcenat, försträckte dem pängar mot hög ränta och god säkerhet, och förkofrade sålunda det svältande landets kapital med all den förtänksamhet, som anstår en klok överhet. ${ }^{76}$

Ahlfors reaktion är intressant:

Det är klartext. Till den grad att det inte kunde användas $i$ ett skådespel 1972 [min emfas]. Om jag hade tagit med sådana stycken, skulle nittio procent av teaterpubliken gått ed på att jag förfalskade Tavaststjerna med anakronistisk propaganda. Bara ordet kapitalist, som I89I kunde användas som en saklig term, hade åttio år senare blivit ett skällsord som ofelbart skulle ha blockerat kommunikationen mellan scen och salong. ${ }^{77}$

Så ansåg också Henry G. Gröndal, i sin recension av premiären, att Bengt Ahlfors tonat ner den bittra och fräna tonen i boken för mycket - pjäsen blir "lika färgdämpad som de otaliga trasmattorna som pryder scenen" ${ }^{78}$

Det är uppenbart att det ännu en gång skett en utveckling i synen på romanen. Från estetiska, psykologiska och idéhistoriska tolkningar har man nu börjat fästa allt större vikt vid textens sociologiska och politiska aspekter. Några källor till denna "7o-talsläsning” ska jag försöka spåra i de två följande avsnitten.

75. Ibid., s. 42 .

76. Tavaststjerna, Hårda tider I891, s. I55.

77. Ahlfors, "Dagbok med Tavaststjerna", s. 43 .

78. Henry G. Gröndal, "Bilder från en brytningstid", Hufoudstadsbladet II/2 I974. 
I954 utkom Väinö Linnas krigsskildring Tuntematon sotilas (sv. Okänd soldat, 1955), 1959-62 hans episka så kallade torpartrilogi. Också i Linnas verk rördes vid "känsliga strängar i vårt nationella medvetande" - för att citera Tavaststjernas försvarsartikel i Finsk Tidskrift I892 - och också Linnas perspektivbyten utsattes genast för skarp kritik från etablerat, förment patriotiskt håll. Okänd soldat bröt mot den äldre, högstämda retoriken kring krigen I939-I945 och särskilt Upp, trälar! (I960), trilogins mellersta del, utmanade en hegemonisk "vit" historieskrivning om det finländska inbördeskriget I9I8 genom att ge en central plats också åt den "röda" sidans perspektiv. Trots den inledande kritiken fick Linnas romaner ändå snabbt klassikerstatus.

Samtidigt med Linnas romanserie växte bland professionella historiker en medvetenhet om den verkliga omfattningen av dödligheten $\mathrm{i}$ fånglägren I9I8 - en annan svältkatastrof, där landets ledning, liksom 50 år tidigare, hade stått handfallen, oförmögen eller ointresserad av att rädda liv. ${ }^{79}$ På ett liknande sätt som efter hungersnöden I867-68 hade makthavarnas andel i ansvaret för katastrofen dittills tonats ner i "segrarnas" historieskrivning.

Bland andra Linna åstadkom en omvärdering i synen på inbördeskriget. Ska den jämförelsevis svaga initiala framgången för Tavaststjernas Hårda tider på i89o-talet tolkas som att den läsande publiken - då starkt begränsad till överklassen, självdefinierad som den "bildade"inte var upplagd för en motsvarande självprövning? Så kan man i varje fall tolka bokens senare renässans i det efterkrigstida Finland, "andra republikens", Paasikivi-Kekkonen-linjens och Linnas Finland.

Kurt Sanmark bäddar för den kopplingen när han i sin recension av nyutgåvan 196r jämför debatten kring Hårda tider med den

79. Viktig för den fördjupade förståelsen var Jaakko Paavolainens forskning kring inbördeskriget, publicerad i tre volymer 1966-71 och sammanfattad i Jaakko Paavolainen, Suomen kansallinen murhenäytelmä: Punainen ja valkoinen terrori ja vankileirit v. I9I8 (sv. Finlands nationella tragedi: Röd och vit terror och fånglägren I9I8), Helsinki: Tammi I974. Enligt nu gällande forskning dog över 14000 personer, de allra flesta "röda", i fånglägren eller strax efter frisläppandet. Statsrådets projekt Krigsdöda $i$ Finland I9I4-I922, http://vesta.narc.fi/cgi-bin/db2www/sotasurmaetusivu/stat2 (hämtad 2I/5 202I). 
kring Linnas och "i viss mening" Christer Kihlmans böcker (Kihlmans romandebut Se upp Salige!, som utkom r96o, gisslar en inkrökt småstadsborgerlighet). ${ }^{80}$

Var Hårda tider ute i otid? I en intressant kommentar till Ekelunds Tavaststjerna och hans diktning pekade P.O. Barck I95I på två möjliga faktorer. ${ }^{81}$ Dels det ökande trycket från den ryska centralmakten, som gärna utnyttjade klassmotsättningarna i Finland. Dels nödårstemat, som när romanen utkom var förnyat aktuellt - den på nytt hotande svälten nämndes, som vi har sett, av bokens första recensent i Hufvudstadsbladet 189 I. $^{82}$

En roman som tycks ifrågasätta den inhemska regeringens förmåga eller vilja att klara av landets problem, som beledsagas av rapporter om ny hungersnöd, allt medan Ryssland stramar åt tyglarna för autonomin - det är möjligt att "det bildade kretsloppet” under sådana förhållanden inte är alltför intresserat av att rota i nödens strukturella orsaker. Som George C. Schoolfield konstaterar i A History of Finland's Literature hade Tavaststjerna "stuckit hål på de nationella myterna om en värdigt och tålmodigt buren misär och en omtänksam överklass". ${ }^{83}$ I och med att en finskspråkig elit börjat etablera sig är det inte bara nationalkänslan på svenskt håll som med Tavaststjernas ord "föga kittlas" - senator med budgetansvar under nödåren var Johan Vilhelm Snellman, en av fennomanernas förgrundsfigurer.

\section{Politikens Återkomst}

Från och med Ekelund 1950 beskriver forskningen i regel mottagandet av Hårda tider som en ideologisk konflikt mellan dels den gamla,

8o. Kurt Sanmark, "Hårda tider”, Hufvudstadsbladet 6/I i96r; för debatten om Christer Kihlmans roman, se min Drag på parnassen. Del I: Medelklass med mänskligt ansikte. Medelklassradikalism i fyra romaner av Christer Kiblman, Jarl Sjöblom, Marianne Alopaeus och Ulla-Lena Lundberg, Helsingfors universitet 2008, http://urn.fil URN:ISBN:978-952-I0-4905-7 (hämtad 2I/5 202I).

8I. P.O. Barck, "Erik Ekelunds Tavaststjerna-bok", Nya Argus I951:3, s. 29.

82. A.B., "Hårda tider".

83. "... he had poked a hole in the national myths of misery nobly and patiently borne and of a caring upper class", Översättning till svenska:TS, George C. Schoolfield, "Finland-Swedish Literature", George C. Schoolfield (ed.), A History of Finland's Literature, Histories of Scandinavian Literature 4 , Lincoln: University of Nebraska Press 1998, s. 363 . 
idealistiska och konservativt kristliga världsbilden, dels en ny, naturvetenskaplig, rationell, realistisk och naturalistisk. ${ }^{84}$ Men inte heller Tavaststjernas samtida,"rationella" krafter tycks ha hittat någon riktigt effektiv användning för boken. Tyder inte den häftiga reaktionen från akademiskt-ideologiskt smakdomarhåll, den relativa tystnaden under förra halvan av I900-talet och den därpå följande renässansen efter I945 på att det rent politiska budskapet i boken har en tyngd, att man har tagit det på allvar - också bland dem som angripit romanen för påstådda sakfel och brister, eller bara förbigått boken?

$\mathrm{Nu}$ finns det förstås en risk att överdriva den "demokratiska tendensen" och samhällskritiken i Hårda tider. Man kan också peka på en minst lika viktig feodal, aristokratisk "tendens", eller på att den rationella kapten Thoreld - möjlig att uppfatta som Tavaststjernas alter ego - på romanens sista sidor lovordar fru von Blumes kristligt medmänskliga moral. ${ }^{85}$

Men visst är det slående hur romanen tycks vakna till nytt liv just under de idémässigt omvälvande i96o- och 70-talen, i och med att en tredje världsåskådning - arbetarrörelsens, som betonar både rationalism av kapten Thorelds snitt och socialt ansvar och inlevelse av fru von Blumes - på allvar börjar tränga in i den litterära institutionens akademiska gren. Studier från denna tid av den finländska I80o-talsrealismens genombrott, som Pertti Karkamas Sosiaalinen konfliktiromaani (sv. Den sociala konfliktromanen, I97I) och Pirkko Alhoniemis Idylli särkyy (sv. Idyllen krossas, I972), kan ses som paralleller till Bengt Ahlfors intresse för Hårda tider. ${ }^{86}$

Basen för den nya läsningen av Hårda tider blir då en "ny" eller nygammal läsning av själva nödåret. Samma år, I972, som Ahlfors tog upp arbetet på pjäsen publicerade Gösta Ågren artikeln "Hungeråren I867-68" i Hufoudstadsbladet. Ågren betonade att svälten inte var någon naturkatastrof, utan en social. ${ }^{87}$ I sitt verk Vår historia (1977) återkom han till ämnet:

84. T.ex. Ekelund, Tavaststjerna och hans diktning, s. I45-I48; Rossi, "Nälkävuosien tunnehallinto", s. 39 .

85. Denna ambivalens påpekas av bl.a. Ekelund, Tavaststjerna och hans diktning, s. 158.

86. Pertti Karkama, Sosiaalinen konfliktiromaani. Rakennetutkimus suomalaisen ybteiskunnallisen realismin pohjalta, Helsinki: Tammi I97I; Alhoniemi, Idylli särkyy.

87. Gösta Ågren, "Hungeråren 1867-68", Hufvudstadsbladet 30/10 1972. 
Men hur var det möjligt? Hur kunde myndigheterna låta en stor del av landets befolkning dö i svält?

Finland var ju dock ett modernt land. Vi hade skolor, universitet, tidningar, lokomotiv och teater. En del av folket kunde läsa. Och ändå dog tiggarna på landsvägskanten som isolerade stenåldersmänniskor $i$ en avlägsen djungel. Kan allt detta verkligen förklaras med att det var de obesuttna som dog och att de obesuttna saknade politisk representation?

Ja. Andra faktorer spelade in, men utan denna grundläggande motsättning hade den här väldiga samhällskatastrofen aldrig inträffat. [...]

Finlands politiska överbyggnad svarade inte mot dess materiella bas. Det fanns fem stånd och det femte ståndet var störst, men ståndssamhället kände endast de fyra högsta stånden och det innebar, att inga som helst politiska kontakter existerade mellan de makthavande och folkets majoritet. ${ }^{88}$

Det är en klassanalys med "demokratisk tendens", i linje med till exempel ekonomen Amartya Sens tes att demokrati och fri press är verksamma medel mot hungersnöd. ${ }^{89}$ Tavaststjernas roman har beröringspunkter med detta strukturella synsätt, kanske till och med fler än med åsikten att svälten kunde ha motverkats genom förnuftiga åtgärder av enskilda individer . von Blumes och Thorelds privatinitiativ beaktas ju inte av senaten; som Ågren skriver spelar andra krafter in. Och en möjlig motkraft - det "femte ståndets" organisering - fanns I89I ännu knappt till som en verklighet, möjlig att beskriva litterärt. I899 grundades Finlands arbetarparti, från och med I903 Finlands Socialdemokratiska Parti. Författaren Elmer Diktonius kommentar i Arbetarbladet 1923 kan ses mot denna bakgrund:

Tavaststjerna reagerade kraftigt, till god för sin ära och vår kärlek, men han hade intet att tillgripa i stället: socialismen och den intel-

88. Gösta Ågren, Vår historia: en krönika om det finlandssvenska folkets öden, en analys av vårt lands historia, Vasa: Skrivor 1977, s. I55.

89. Avsaknad av en fri press kan enligt Sen göra en regering till fånge för sin egen propaganda, som t.ex.i Kina under"det stora språnget"i slutet av i950-talet. Referat i Hirvonen, Tiedon, tabdon vai resurssien puutetta?, s. 8 och Ir. 
lektuella kosmopolitismen var då ännu så gott som okända begrepp vid denna breddgrad. Det skapade tragiken i hans liv. ${ }^{90}$

Klart är åtminstone att Tavaststjerna i Hårda tider avvisar den runebergska och topelianska synen på svälten som en gudasänd, självförvållad prövning eller ett syndastraff - så som han parodierar denna tanke i dottern i familjen von Blume, den unga Louises funderingar:

hon hade helt enkelt genom sitt uppförande undvikit att förtörna Gud och därför sluppit det hårda straffet, som drabbade alla de fattiga. [...] Och hon kom till den mogna öfvertygelsen att herrskapsfolket ändå stod himmelshögt öfver bönderna i vandel och hjärtats renhet, då Gud lät dem gå så fria från straff. Eller också hade Jesus dött på korset specielt för dem och sålunda försonat bara en del af människosläktets synder. ${ }^{91}$

Agathon Meurman kan ha varit i god tro när han utifrån en - kan det tyckas - liknande världsbild som Louises, anklagar Tavaststjerna för folkförakt: "Var då denna det finska folkets hjeltestrid af sådan art!" Men det är oroande att med dagens ögon läsa hans försvar för regeringens beslut att inte, som under tidigare missväxt, dela ut gratis säd som nödhjälp. Att inte göra det stärkte nämligen enligt Meurman ansenligt det döende folkets moral. ${ }^{92}$ Resonemang av detta slag kallas i dag "kreativ förstörelse" och nyliberalism.

Därför kan man fråga om Sanmarks ordval är det rätta när han I96I kallar Ernst Gråstens berömda kritik I892 av Hårda tider för ett

90. Elmer Diktonius, "Tavaststjerna och den nya dikten. Reflexioner inför den 25 -te årsdagen av hans död, den 20 mars", Arbetarbladet I6/3 I923. Till skillnad från Diktonius, och med tanke på tidpunkten för romanens händelser, känns Karkamas kommentar något snäv när han skriver att den sociala problematiken i Hårda tider stannar i bakgrunden till förmån för de dramatiska händelserna: "De samhälleliga motsättningarna kan redan skönjas, men Tavaststjerna låter dem inte utvecklas". Översättning: TS. Karkama, Sosiaalinen konfliktiromaani, s. 30I. Av samma orsak kan man ifrågasätta kronologin i Mazzarellas konstaterande att "en gestalt som Lehtimaa kommer till vid en tidpunkt då arbetarrörelsen redan börjat ställa ganska högljudda krav". Merete Mazzarella, "Efterord”, K.A. Tavaststjerna, Hårda tider, I991, s. I9I.

91. Tavaststjerna, Hårda tider I89I, s. I48.

92. Meurman, ”Nälkävuodet", s. 4 . 
exempel på "hur även den s.k. auktoritativa kritiken kan hugga i sten". ${ }^{93}$ Utgår man från Gråstens eller Meurmans egen samhällssyn var deras kritik både följdriktig och i linje med statsledningens intressen. Deras motattack var dessutom effektiv. Riikka Rossi betecknar det som en historiens ironi att inte Tavaststjernas roman utan Meurmans reaktion på den, hans försvar för den av J.V. Snellman ledda senaten, kom att prägla den finländska historieskrivningen för en lång tid framåt. ${ }^{94}$ Enligt historikern Tuomas Jussila behöll Meurmans skrift sin ställning som standardverk inom forskningen ända in på 1980-talet. ${ }^{95}$

Samtidigt kan man spekulera kring hur nödvändig Tavaststjernas egen taktiska reträtt var, med strykningarna i den finska utgåvan och betonandet i hans "Sjelfförsvar" av verkets "rent skönlitterära" sida.

Under hungeråret 1867 okade exporten av råg från Finland med I6 procent jämfört med medeltalet för decenniet, samtidigt som produktionen drastiskt minskade. Också havre-, smör- och fiskexporten ökade. ${ }^{96}$ För att återknyta till Gösta Ågrens analys: också detta kan ses som ett utslag av bristande kontakt mellan de makthavande (inklusive de ekonomiska) och folkets majoritet.

\section{Slutord. Tavaststjerna, Kivi och Häda tiders PLATS I KANON}

- En hård början drabbade Hårda tider. Berättelse från Finlands sista nödår. Efter några positiva recensioner satte ett tungt artilleri av fördömanden in. Det var en reaktion av samma slag som August Ahlqvists berömda sågning av Aleksis Kivis roman Seitsemän veljestä (Sju bröder) två decennier tidigare - ett annat "bokkrig" mot en blivande klassiker. ${ }^{97}$

93. Sanmark, "Hårda tider".

94. Rossi, "Nälkävuosien tunnehallinto", s. 39.

95. Tuomas Jussila, "'Saarijärwen Paawosta ei näy wiwahdustakaan'. Nälkävuodet ja kirjallisuus" [sv. "Av Saarijärvis Paavo syns inte ens en skymt". Hungeråren och litteraturen], Tuomas Jussila \& Lari Rantanen (toim.), Nälkävuodet 1867-1868, Suomalaisen Kirjallisuuden Seuran toimituksia I443, Helsinki: Suomalaisen Kirjallisuuden Seura 2018, s. 257.

96. Kaarina Vattula (toim.), Suomen taloushistoria 3, Historiallinen tilasto, Helsinki: Tammi i983, s. I88.

97. Se t.ex. Salminen,"X. I860-I880: Finland", s. II9; Kai Laitinen, Finlands litteratur, Helsingfors: Söderström \& Co I989, s.I07. 
- I bägge fallen framträdde personer inom den akademiska och politiska hegemonin, kränkta och sårade av de litterära verken. Romanerna upplevdes av kritikerna som angrepp på den idealistiska världsbild som vi i dag förknippar med författare som Runeberg och Topelius.

- I sin samtid fick varken Kivi eller Tavaststjerna något avgörande offentligt stöd från sina finländska författarkolleger eller från landets övriga intelligentia.

- Till skillnad från Kivi drog Tavaststjerna själv ut i försvar för sin roman. Han kunde bland annat åberopa beröm från tunga nordiska kolleger. En annan skillnad är Tavaststjernas mera prononcerade naturalism i Hårda tider, samt verkets politiska udd. Där Kivi gör narr av byns klockare, alfabetiseringens representant, riktar sig Tavaststjernas sarkasmer långt högre upp: mot överklassens, kyrkans och regeringens relativa handfallenhet inför eller till och med utnyttjande av hungerkrisen.

- En del av dessa sarkasmer ströks när romanen översattes till finska.

- Under första halvan av I900-talet är det relativt tyst om romanen. Uppgörelsen med idealismen noteras i handböcker. En parallell dras mellan ett mord i romanen och det socialistiska revolutionsförsöket I9I8 - ett aktualiserande bruk av den naturalistiska personskildringen på gränsen till spekulation kring folkkaraktärer.

- Efter andra världskriget ser den litterära institutionen med ökad förståelse på Tavaststjernas samhällskritiska ansats. Det sker samtidigt som historiker på bredare front anammar den kritik mot regeringens svaga insatser under svältkrisen som Tavaststjerna (I89I) och Edvard Gylling (I9I7) fört fram. ${ }^{98}$ Kanske det är först nu romanens budskap blir mera allmänt accepterat och får sin plats i ett kritiskt historiebruk.

- Ändå är det anmärkningsvärt att romanens ord om kapitalisternas "glänsande spekulationer i landets nöd" ännu I972, 8I år efter utgivningen, sågs som så kontroversiella - aktuella? - att författaren-regissören av pjäsversionen för Svenska Teatern ansåg det nödvändigt att dämpa budskapet. ${ }^{99}$

- Trots skiftande konjunkturer och bruk av romanen har den en stabil plats i kanon, med ett flertal utgåvor på svenska och finska. Också översättningar till norska, danska och tyska föreligger. En

98. Gylling, "Nälkävuodet I867-68"; jfr Gösta Ågren, Vår historia, s. I55.

99. Ahlfors, "Dagbok med Tavaststjerna", s. 43. 
relativ tystnad och lucka i tillgängligheten uppstod mellan de svenskspråkiga nyutgåvorna 1924 och 196r. Den senaste svenskspråkiga tryckta utgåvan utkom 2004. Ett flertal digitala utgåvor av Hårda tider är i skrivande stund fritt tillgängliga på nätet. ${ }^{100}$ Tavaststjerna har fått sin revansch, även om han inte själv fick uppleva den.

Ioo. Se not 34 . 